\title{
Effects of protein oxidation on the texture and water-holding of
} meat : a review

\section{Bao, Yulong}

2019

Bao , Y \& Ertbjerg , P 2019 , ' Effects of protein oxidation on the texture and water-holding of meat : a review ' , Critical Reviews in Food Science and Nutrition , vol. 59 , no. 22 , pp.

3564-3578 . https://doi.org/10.1080/10408398.2018.1498444

http://hdl.handle.net/10138/310246

https://doi.org/10.1080/10408398.2018.1498444

acceptedVersion

Downloaded from Helda, University of Helsinki institutional repository.

This is an electronic reprint of the original article.

This reprint may differ from the original in pagination and typographic detail.

Please cite the original version. 


\title{
Effects of protein oxidation on the texture and water-holding of meat: A
}

\section{review}

Yulong Bao ${ }^{\mathrm{a}, \mathrm{b}}$, Per Ertbjerg ${ }^{\mathrm{b}, *}$

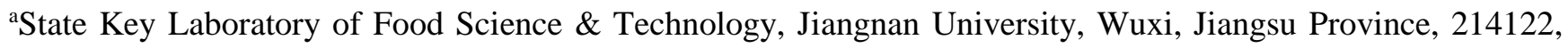

China

bepartment of Food and Nutrition, University of Helsinki, 00014, Helsinki, Finland

*Corresponding author: Tel.: +358 503183909; E-mail address: per.ertbjerg@helsinki.fi

\begin{abstract}
Protein oxidation readily occurs in post-mortem muscle during storage and processing. Over the past decade new analytical methods have been developed and new aspects of protein oxidation in meat have been studied, such as the reaction mechanism, and impacts on eating quality and nutritional value. It is now evident that amino acid side chains in myofibrillar proteins undergoes modifications due to oxidative stress. In turn this will lead to formation of new protein-protein cross-links in structural proteins, however, also the overall level of fixed-charge groups attached to the peptide backbones is modified. Meat texture and water-holding are important quality attributes and they are affected by the oxidation of structural proteins. Different mechanisms have been suggested to explain the oxidation-induced quality changes, focusing mainly on reduced proteolysis and formation of cross-links. This review explores the current understanding of protein oxidation in fresh meat in relation to texture and water-holding. The consequences of protein oxidation at molecular level in relation to oxidation-induced cross-linking and changes in net charges of myofibrillar proteins, and the impacts on texture and water-holding are discussed.
\end{abstract}

Keywords: meat structure, net charge, meat quality, oxidized proteins, protein cross-links, histidine

\section{Introduction}

Protein oxidation has in many studies been in focus in the medical area owing to the relationship between oxidation-induced damages of proteins and age-related diseases (Berlett and Stadtman 1997). Protein is one of the major components in many foods and, therefore, oxidation-induced damages to proteins, if accumulated to certain levels, is expected to affect food quality. Meat, being a protein-rich food and containing pro-oxidants, such as lipids and myoglobin, is susceptible to oxidation. Oxidative conditions 
readily occur in post-mortem muscle and several excellent review papers have discussed the general mechanisms of muscle protein oxidation and its impact on the eating quality and nutrition of meat (Estévez 2011; Lund et al. 2011; Soladoye et al. 2015; Zhang, Xiao, and Ahn 2013).

Texture and water-holding are important meat eating quality traits as they greatly influence sensory properties and therefore the economic value of meat. These properties have been extensively studied. Nonetheless, the mechanisms defining meat tenderness and water-holding capacity are only partly understood as the meat structure is very complex. Meat texture is greatly affected by the amount and quality of the connective tissue, the sarcomere length as the muscle enters rigor mortis, and the degree of proteolysis during chilled storage. Water-holding capacity is in addition influenced by phenomena at the myofibrillar, myofilamental and protein level (Ertbjerg and Puolanne, 2017; Huff-Lonergan and Lonergan, 2005). Electrostatic forces, osmotic forces and capillary forces are all phenomena affecting the location of water molecules in the meat structure (Puolanne and Halonen, 2010), and these forces are in turn affected by charges of amino acid side chains, hydrophilic and hydrophobic areas of the proteins, and the interaction with structural elements within the sarcomere and between the myofibrils. Further effects arise due to oxidative modifications of proteins. An elaboration about the effects of protein oxidation on texture and water-holding provides beneficial information for meat processors and consumers. This review aims to explore effects of protein oxidation on the texture and water-holding of meat and the underlying mechanisms, with a focus on meat structure and a novel perspective of protein net charges.

\section{Effects of protein oxidation in meat on filament charges and protein cross-linking}

Protein oxidation is believed to start from the abstraction of a hydrogen atom in the protein by reactive oxygen species (ROS). ROS is a collective term that includes oxygen-containing radicals (such as $\mathrm{O}_{2}{ }^{\circ}$, ${ }^{\circ} \mathrm{OH}, \mathrm{RO}^{\cdot}, \mathrm{RO}_{2}{ }^{\circ}$ ) and also some non-radical derivatives of oxygen (such as $\mathrm{H}_{2} \mathrm{O}_{2}, \mathrm{HClO}, \mathrm{O}_{3}$ ). ROS can be produced during normal metabolism of muscle and also upon exposure of meat to exogenous factors including oxygen in modified atmosphere packaging (MAP), irradiation and chemical reagents. The nature of ROS is of importance for the resulting oxidative reactions. The hydroxyl radical $\left({ }^{\circ} \mathrm{OH}\right)$ is very reactive and it can initiate oxidation in proteins and lipids. In meat and meat model systems, the $\mathrm{H}_{2} \mathrm{O}_{2-}$ activated metmyoglobin can generate very potent oxidants (Baron and Andersen 2002; Irwin, Østdal, and Davies 1999). Oxidized lipids have also been used to initiate protein oxidation in meat (Park and Xiong 2007; Xiong, Park, and Ooizumi 2009) as radicals can transfer between lipid and protein (Schaich and Pryor 1980). Hypochlorous acid ( $\mathrm{HClO})$ is a strong oxidant that is able to mediate protein oxidation (Hawkins, Pattison, and Davies 2003; Pattison and Davies 2006; Pattison, Hawkins, and Davies 2007). Soglia, Petracci, and Ertbjerg (2016) found that $\mathrm{HClO}$ is very efficient in introducing protein oxidation in meat, as they observed marked increase of carbonyl groups in all analyzed protein fractions after incubation of minced meat with $\mathrm{HClO}$. 
Protein is the most abundant constituent of lean meat except water. Oxidative modifications of proteins can have a large impact on meat quality. The general consequences of protein oxidation in meat and the effects on filament charges and protein cross-linking are described and discussed below.

\subsection{Amino acid sidechain modifications}

Essentially all amino acids can be oxidized (Davies and Dean 1997). As reviewed by Lund et al. (2011), cysteine, tyrosine, phenylalanine, tryptophan, histidine, proline, arginine, lysine and methionine are particularly susceptible to ROS. It is often difficult to detect small losses of amino acids by composition analysis following hydrolysis due to poor method sensitivity. Analysis for oxidation products is a more sensitive approach for detection of oxidative damage. Park and Xiong (2007) investigated the oxidative modifications of amino acids in myofibrillar proteins which were exposed to three different oxidizing systems (an iron-catalyzed oxidation system, a lipid oxidizing system, and a metmyoglobin oxidizing system). Cysteine was the only amino acid residue that decreased in all three oxidizing systems. The thiol group of cysteine residue is highly susceptible to oxidation and loss of thiol groups has been widely used as a marker for protein oxidation in meat (Delles and Xiong 2014; Lund et al. 2007; Martinaud et al. 1997).

The formation of carbonyls is another important side-chain modification in oxidized proteins. For a thorough review on protein carbonyls in meat, see Estévez (2011). The original method for carbonyl determination (Levine et al. 1990) has been adopted and modified to optimize the detection of carbonyls in muscle proteins (Decker et al. 1993; Fagan, Sleczka, and Sohar 1999; Soglia, Petracci, and Ertbjerg 2016). Soglia et al. (2016) introduced treatments including addition of SDS, heating, and ultra-sonication for TCA precipitated protein before derivatization with DNPH, and found that those additional steps overall resulted in two to four fold more carbonyls measured in meat from different species as well as in different protein fractions. The detection of specific carbonyls, lysine-derived $\alpha$-amino adipic semialdehyde (AAS) and arginine- or proline-derived $\gamma$-glutamic semialdehyde (GGS), enables in-depth study of the relationship between carbonylation and functionalities of myofibrillar proteins (Utrera and Estévez 2012). Estévez (2011) regarded the major protein-derived carbonyls in meat as AAS and GGS. In addition to the amino acids resulting in AAS and GGS, other amino acids may oxidize into carbonyl products as well. The histidine-derived carbonyl, 2-oxo-histidine, has been detected in many proteins subjected to in vitro oxidation (Uchida 2003); and also the amount of histidine in myofibrillar proteins was found to become lower when exposed to a metmyoglobin oxidizing system, indicating the oxidation of histidine (Park and Xiong 2007). More recently, the histidine content in myofibrils was found to decrease with $\mathrm{HClO}$-mediated oxidation, and the decrease was at the same magnitude as the formation of carbonyls (Bao, Boeren, and Ertbjerg 2018). Oxidation of histidine was likely a main contributor of the increased carbonyls. Therefore, in addition to the use of AAS and GGS as markers of protein oxidation in meat, it is of interest to focus on histidine derived carbonyls in meat as well. 


\subsection{Oxidation and protein charges}

The biological and biophysical properties of proteins are greatly affected by mobile electrolyte ions and by ionized fixed-charge groups attached to the peptide backbones. It is, therefore, critical to understand the influence of protein charges on meat quality traits. Oxidative modifications of amino acid sidechains are occurring under oxidative stress and can lead to altered protein charges in meat (Estévez et al. 2011; Utrera and Estévez 2012). Consequently, the concept of protein charges may offer a novel perspective to understand the mechanisms behind oxidation-induced meat quality changes.

\subsubsection{Origin of protein charges}

Several amino acid sidechains can exist in basic or acidic forms, depending on their $\mathrm{pK}_{\mathrm{a}}$ values and the $\mathrm{pH}$ of the solution. The Henderson-Hasselbalch equation describes the relationship between $\mathrm{pH}, \mathrm{pK}_{\mathrm{a}}$ and the dissociation of a weak acid (Equation 1) or weak base (Equation 2).

$$
\begin{array}{ll}
\mathrm{pH}=\mathrm{pK}_{\mathrm{a}}+\log _{10}\left(\frac{\left[\mathrm{A}^{-}\right]}{[\mathrm{HA}]}\right) & \text { Equation 1 } \\
\mathrm{pH}=\mathrm{pK}_{\mathrm{a}}+\log _{10}\left(\frac{[\mathrm{B}]}{\left[\mathrm{BH}^{+}\right]}\right) & \text {Equation 2 }
\end{array}
$$

Based on Equation 1 and 2, when the $\mathrm{pH}$ is much lower than the $\mathrm{pK}_{\mathrm{a}}$ of acid or base, the protonated form predominates. In this case the acidic side chain has a charge close to 0 and the basic side chains a charge close to +1 . Conversely, when the $\mathrm{pH}$ is much higher than the $\mathrm{pK}_{\mathrm{a}}$, the deprotonated form predominates, resulting in acidic side chains with a charge close to -1 and basic side chains a charge close to 0 . The acid or base form that is prevalent at $\mathrm{pH}$ of 5.5 (around ultimate $\mathrm{pH}$ of meat) is marked in red in Fig. 1. It should be noted that in folded proteins, the actual dominant form of amino acid residues also depends on the local environment (Kuriyan et al. 2012). For example, a charged residue is energetically unfavorable in a hydrophobic environment but favorable when there is charged residues interacting with it. Thus in folded proteins, the $\mathrm{pK}_{\mathrm{a}}$ values of amino acid residues may differ significantly from those in Fig. 1.

\subsubsection{Charges at protein and filament level}

Charges in meat can be studied at individual protein and at filament level. Hamm (1972) studied the amount of positively and negatively charged groups of muscle proteins in relation to $\mathrm{pH}$ using a dyebinding assay and the results are presented in Fig. 2. Based on Fig. 2, at the $\mathrm{pH}$ of living muscle (pH close to 7), aspartic acid and glutamic acid predominantly exist in the form with a charge of -1 ; histidine, tyrosine and cysteine remain neutral; lysine and arginine are in +1 charged form. This gives a net charge around $\left(14.2^{-}\right)+\left(7.4^{+}\right)+\left(3.8^{+}\right)=3$ (mole e / $10^{4} \mathrm{~g}$ actomyosin). After slaughter when the muscle approaches the typical ultimate $\mathrm{pH}$ of 5.5 , histidine will shift from being mainly neutral to mainly positively charged, while other charged amino acid residues almost remain unaffected. This leads to a decreased net negative charge of $\left(3^{-}\right)+\left(1.8^{+}\right)=1.2$ (mole e $/ 10^{4} \mathrm{~g}$ actomyosin). The values for net charges mentioned here are rough estimations, other factors like bound ions have an effect on net charges as well. As an example, Hamm (1960) found that at $\mathrm{pH} 7 \mathrm{more} \mathrm{Mg}^{2+}$ and $\mathrm{Ca}^{2+}$ ions were bound to 
myofibrillar proteins compared to $\mathrm{pH}$ 5.5. From living muscle to post-mortem muscle, histidine gradually changes from neutral to positively charged form. This may be one of the key factors to understand meat quality changes early post-mortem.

The isoelectric point (pI) of muscle proteins can be estimated based on protein sequences and also be measured by isoelectric focusing. The isoelectric point can vary a lot between protein subunits as shown in different myosin fragments (Béchet and d'Albis 1989). A major part of the sarcoplasmic proteins have pI values between 6 and 7 (Bendixen 2005) and the myofibrillar proteins as a whole has a pI around 5.0 (Hamm, 1972). Therefore, myofilaments are negatively charged in fresh meat as the ultimate $\mathrm{pH}$ is generally around 5.5. According to Naylor et al. (1985), the Donnan potential together with the principle of electrical neutrality can be used to estimate the fixed charges on the myofilaments. The measured Donnan potentials in rabbit psoas muscle in rigor were electrically neutral (indicating the $\mathrm{pI}$ ) at $\mathrm{pH} 4.5$ in $10 \mathrm{mM} \mathrm{KCl}$, or at pH 5.2 in $50 \mathrm{mM} \mathrm{KCl}$. Therefore, the pI of the proteins depends on ionic strength as well. In agreement, salt has been shown to affect pI of muscle proteins (Hamm 1972).

\subsubsection{Effect of protein oxidation on protein charges}

Protein carbonylation usually involves loss of lysine, arginine, and histidine residues (Stadtman and Levine 2003). These amino acids can exist in positively charged forms and, thereby, affect protein charges. Therefore, protein carbonylation affect protein net charges. Davies (1987) used isoelectric focusing (IEF) to detect alterations in the primary structure caused by oxidation. IEF separates proteins based on their $\mathrm{pI}$ and both positive and negative charge changes were observed with various proteins subjected to oxidation. Davies, Delsignore, and Lin (1987) found that bovine serum albumin shifted to a lower $\mathrm{pI}$ following oxidation. In agreement, Baraibar et al. (2011) reported that oxidative stress led to a shift of some proteins in human myoblasts to lower pI values. In meat, protein carbonylation has been suggested to result in modified electronic arrangement of myofilaments (Estévez et al. 2011; Utrera and Estévez 2012). So far, only very limited is available on the changes of protein charges in meat as affected by oxidation. Sun et al. (2013) studied the changes in Zeta-potential of emulsions prepared from oxidized myofibrillar proteins and found a shift of $\mathrm{pI}$ of the emulsion droplets to lower values. The lower $\mathrm{pI}$ values were attributed to oxidation-induced loss of basic amino acid residues, production of more acetic residues, or increase of previously buried ionisable groups. More recently, Bao et al. (2018) directly measured the isoelectric point of oxidized myofibrillar proteins by IEF and observed a general shift of protein bands towards a lower $\mathrm{pI}$ following oxidation. Affected proteins were identified as mainly myosin heavy chain, myosin light chain, actin and tropomyosin. Those proteins account for approximately $73 \%$ of the myofibrillar proteins and locate in either myosin filaments or actin filaments. Lower pI values of myofibrillar proteins bring the average $\mathrm{pI}$ of muscle proteins towards the more acidic area, and therefore the difference between the average $\mathrm{pI}$ and experimental $\mathrm{pH}$ (5.5) became larger, indicating that oxidation increased the overall net negative charges of myofibrillar proteins. A limitation of IEF gel electrophoresis is that this technique only allows analyses of solubilized proteins while solubilization of oxidized myofibrillar proteins is difficult. To obtain information on more insoluble proteins also, an amino acid analysis on the acid hydrolysates of the myofibril pellets was performed, and histidine was found to 
decrease with oxidation (Bao et al. 2018). It was hypothesized that some of the histidine side chains formed carbonyls and thereby lost their positive charges upon oxidation. Therefore, the observed loss of histidine supports the hypothesis that oxidation leads to an increase of net negative charge on actin and myosin filaments.

\subsection{Formation of protein cross-links}

Formation of cross-links is one of the most common consequences of protein oxidation in meat (Lund et al. 2011). Protein cross-linking refers to the formation of covalent bonds within a protein (intramolecular) or between proteins (intermolecular). Several pathways lead to oxidation-induced protein cross-linking (Stadtman and Levine 2003) and some of them are relevant in meat systems (Fig. 3) as discussed in the following.

\subsubsection{Different types of protein cross-linking in meat}

\section{Formation of disulfide through oxidation of cysteine thiol groups}

One of the oxidized products of cysteine is the disulfide cross-link (Fig. 3a). SDS-PAGE results under reducing and non-reducing conditions have indicated the formation of disulfide-linked protein polymers in high oxygen packaged beef (Bao, Puolanne, and Ertbjerg 2016; Kim et al. 2010) and pork (Delles and Xiong 2014; Lund et al. 2007), as well as in chemically oxidized myofibril extracts (Decker et al. 1993; Liu and Xiong 2000; Xiong, Park, and Ooizumi 2009). Disulfide formation is a common outcome of oxidative stress and many reactions lead to disulfides, such as interactions of thiols with sulfenic acids, conversion of thiosulfinate or thiolsulfonate esters, and radical-mediated thiol oxidation (Nagy and Winterbourn 2010). The common strategy for detection of disulfides involves 3 steps: 1) blocking the free thiol group, 2) reducing the disulfides, and 3) detecting newly reduced thiols (Rysman et al. 2014). The disulfide bond is regarded as the main oxidation-induced cross-linking type in fresh meat, however, other types of cross-links are present in meat as well (Lund et al. 2011).

\section{Formation of dityrosine through interaction of two tyrosine radicals}

Tyrosine is one of the primary targets for oxidation by various ROS, and it can be converted to dityrosine (Fig. 3b), a specific marker for protein oxidation (Davies, Delsignore, and Lin 1987; Giulivi and Davies 1993). Formation of dityrosine has been reported in meat model systems (Bertram et al. 2007; Lund et al. 2008; Morzel et al. 2006; Xiong et al. 2009) and recently also in meat (Zhang et al. 2017). Bertram et al. (2007) showed that $\mathrm{pH}$ had a great effect on the formation of dityrosine and the formation was much higher at $\mathrm{pH} 5.5$ than at $\mathrm{pH}$ 7.0. It is not clear if dityrosine can be a good marker of protein oxidation in meat due to limited available knowledge. 


\section{Carbonyl group mediated cross-linking}

Protein carbonyls resulting from oxidation are reactive and has been described in detail in an excellent review by Estévez (2011). Carbonyls may thus further react with lysine $\varepsilon$-amino groups which results in protein cross-linking (Fig. 3c), or two specific carbonyls AAS could form an aldol condensation product also leading to cross-linking (Fig. 3d). Other than protein-derived carbonyls, lipid oxidation also generates carbonyl compounds (such as malondialdehyde, MDA), which can react with the $\varepsilon$-amino group of lysine residues in proteins. In theory, the oxidation reactions can be transferred between lipids and proteins (Zhang et al. 2013). Reactions of both carbonyl groups of MDA with two different lysine residues is another pathway leading to protein cross-linking (Fig. 3e). Buttkus (1967) showed that MDA reacted with myosin $\varepsilon$-amino groups and lysine was among the most reactive amino acid residues. Xiong et al. (2009) found an increased amount of protein-bound MDA in myofibrillar proteins exposed to different oxidizing systems, and they suggested that MDA contributed to the cross-linking of oxidized myofibrillar proteins. It has also been shown that other aldehydes than MDA are susceptible to form adducts with proteins, such as 4-hydroxy-2-nonenal (HNE) (Aldini et al. 2005; Suman et al. 2006) and 4-hydroxy-2-hexenal (HHE) (Yamada et al. 2004). Therefore, oxidized lipids may serve as a pool of reactive species which can react with proteins leading to protein cross-linking.

\subsubsection{Cross-linking of structural proteins}

In meat model systems subjected to oxidative stress, protein aggregates are generally formed (Decker et al. 1993; Martinaud et al. 1997; Morzel et al. 2006; Santé-Lhoutellier, Aubry, and Gatellier 2007; Xiong et al. 2009). Decker et al. (1993) incubated myofibrillar proteins with oxidants and observed marked loss of myosin and actin bands in SDS-PAGE (non-reducing conditions). Myosin and actin apparently formed cross-linked products which were too large to enter the gel. Martinaud et al. (1997) concluded that myosin is the most oxidizible among the myofibrillar proteins. Xiong et al. (2009) investigated the cross-linking pattern of porcine myofibrillar proteins, and found that the tail part of myosin was a favourable region for cross-linking. Lund et al. (2007) studied effect of high oxygen MAP on protein oxidation of pork during chill storage, and observed cross-linked myosin heavy chain in high oxygen packaged but not in vacuum skin packaged meat, indicating that oxidation induced protein cross-linking. The loss of free thiols suggested that disulfides participated in cross-linking and this was confirmed by the observation that cross-linked protein bands disappeared under reducing conditions. By using 2D diagonal-PAGE, Kim et al. (2010) obtained results suggesting that intermolecular cross-linking might have occurred between myosin heavy chain and titin. Cross-linked myosin heavy chain has been observed as a major oxidation product in high oxygen packaged meat in other studies as well (Bao and Ertbjerg 2015; Bao et al. 2016; Moczkowska et al. 2017; Rysman et al. 2014).

Collagen is a significant part of proteins in meat, and knowledge about oxidation of collagen in postmortem muscle is limited in the literature. It is generally accepted that collagen in the intramuscular connective tissue develops more mature cross-links as animal grows older (reviewed by Purslow 2005). 
Cross-linking of collagen has been shown when exposed to hydroxyl radicals (Kano, Sakano, and Fujimoto 1987), ozone or UV radiation (Fujimori 1988). In contrast, fragmentation of collagen were also reported in metal catalyzed oxidation (Uchida, Kato, and Kawakishi 1992) and UV irradiation (Kato, Uchida, and Kawakishi 1992). Protein backbone fragmentation has been regarded as one of the common consequences of oxidation (Stadtman and Levine 2003). Unlike cross-linking, which has been shown in meat and meat model systems; no direct evidence for oxidation-induced protein fragmentation has been found in meat.

In meat products, compounds from other sources are often added. Oxidative enzymes (e.g. tyrosinase, laccase) that have been used in meat model systems can facilitate formation of protein cross-links (Lantto et al. 2007). Some phenolic-rich plant extracts have been used as antioxidants in meat (Juntachote et al. 2006; Wagh et al. 2015) and by retarding oxidative reactions they have the potential to prolong the self life of meat products. Jongberg et al. (2013) found that addition of green tea extract to the recipe of Bologna type sausage enhanced protein polymerization and the polymerization was ascribed to interactions between quinone compounds from tea extract and thiol groups of muscle proteins.

\subsubsection{Detection of protein cross-linking}

Disulfide cross-linking can be both intra- and inter-molecular. Diagonal PAGE has been used as a tool to distinguish the two types of protein cross-linking (Winger et al. 2007). The diagonal PAGE is a 2D gel which separates proteins based on molecular weight first under non-reducing condition and then under reducing condition (Fig. 4). This technique has been used to study protein cross-linking in high oxygen packaged beef (Kim et al. 2010; Moczkowska et al. 2017). Some of the myofibrillar proteins (e.g. titin and nebulin) have a very large molecular weight and low solubility. Inter-molecular protein crosslinking leads to even larger and less soluble molecules, thereby making the analysis of oxidized proteins by gel electrophoresis rather difficult. Warren, Krzesinski, and Greaser (2003) developed a vertical agarose gel electrophoresis system that allows separation of titin and other high molecular weight products.

Particle size as determined by laser diffraction has been previously used as a fast and simple method to evaluate myofibril fragmentation in meat (Karumendu et al. 2009; Lametsch et al. 2007), and it has also been used to study the textural properties of wooden breast chicken muscle (Soglia et al. 2017). Intermolecular protein cross-linking is expected to increase particle size of meat homogenates. Therefore, particle size can be used as an indicator of oxidation-induced protein cross-linking.

\section{Effects of protein oxidation on texture and water-holding}

Texture and water-holding are important meat quality traits as they are linked to sensory acceptability and therefore the economic value. Several papers thoroughly reviewed the biochemical and/or 
biophysical basis for texture (Bailey 1972; Ertbjerg and Puolanne 2017; Huff-Lonergan, Zhang, and Lonergan 2010; Tornberg 1996) and water-holding (Ertbjerg and Puolanne 2017; Huff-Lonergan and Lonergan 2005; Offer and Knight 1988; Pearce et al. 2011; Puolanne and Halonen 2010) of meat. Although many factors influence texture and water-holding, changes in these two meat quality traits are often through key changes to the structure of muscle proteins and their spatial arrangement (Hughes et al. 2014). Oxidative modification may lead to protein cross-linking and affect protein net charges (as discussed in the previous section), and thereby influence the structure of muscle proteins and their spatial arrangement. Protein oxidation readily occurs in post-mortem muscle during storage and processing. The impact of protein oxidation on texture and water-holding of meat is introduced below.

\subsection{Oxidation-induced meat toughening}

An overview of the literature on the relationship between oxidative conditions and textural properties of meat with focus on oxygen in packaging is summarized in Table 1 and studies on meat model systems using either chemical oxidation such as the Fenton reaction or irradiation is summarized in Table 2. Although a few of these studies did not find a significant toughening effect due to oxidation, the consensus is that oxidative conditions, such as high oxygen MAP and irradiation, generally lead to decreased tenderness or increased shear force of meat, as observed in beef (Kim et al. 2010; Lagerstedt, Lundström, and Lindahl 2011), pork (Bao and Ertbjerg 2015; Lund et al. 2007), lamb (Bórnez et al. 2010; Kim et al. 2012), and chicken (Yoon, 2003). Some of the studies found that the toughening effect depends on animal species (Lund et al. 2008), animal age (Kim et al. 2012), or muscle type (Kim et al. 2010). The meat toughening effect is often accompanied by formation of protein cross-links (Bao and Ertbjerg 2015; Kim et al. 2010; Lund et al. 2007; Moczkowska et al. 2017; Jongberg et al. 2014). Some studies have shown increased lipid oxidation in parallel with texture changes. However, the extent of the direct effect of lipid oxidation on texture is difficult to assess as lipid oxidation may transfer the oxidative stress to protein (Liu, Lampi and Ertbjerg 2018) and therefore also affect texture through protein oxidation. Oxidation-induced textural changes were also demonstrated on single muscle fibres isolated from cooked meat samples (Lund et al. 2008) where the breaking force of bovine LD muscle fibres increased in high oxygen MAP, indicating that texture changes occurs at the level of the muscle fibre. It is currently not known if oxidation of connective tissue is also involved in the observed texture changes. Two mechanisms have been proposed for oxidation-induced changes in meat texture: toughening through formation of protein cross-links and less tenderization through reduced proteolysis.

\subsubsection{Role of protein cross-linking}

Formation of mature cross-links in collagen during animal aging is known to increase meat toughness (Purslow 2005), and likewise can oxidation-induced protein cross-links in myofibrils be assumed to contribute to textural changes of meat.

Protein cross-linking affects the elastic pressure $(P)$ of a gel and $P$ is given by: 
$P=\frac{R T\left(v_{e} / V_{0}\right)}{q^{1 / 3}} \quad$ Equation 3

where $q$ is the amount of swelling, $R$ is the gas constant, $T$ is the absolute temperature, $v_{e}$ is the number of cross-linked units in the unswollen volume $V_{0}$ (Flory 1953). It can be seen from Equation 3 that with increasing number of cross-links, the higher the elastic pressure and therefore the gel will be more resistant to deformation. In agreement, Wang, Luo and Ertbjerg (2017) found that a stronger myofibrillar protein gel was linked to more protein cross-linking. Although muscle is much more ordered than a protein gel, there are sufficient general common principles involved. Oxidation-induced cross-links may add to the heat-induced cross-links formed in meat during cooking and therefore increase the elastic pressure of meat leading to tougher meat.

Myofibrillar protein cross-linking has been regarded as one of the explanations for the toughening effect in meat with short sarcomeres (Bailey 1972). In contracted sarcomeres, the altered structure with greater overlap of myosin and actin filaments may permit the formation of more disulfide bonds, leading to tougher meat. In high oxygen packaged pork, formation of disulfide bonds and lower tenderness were observed by Lund et al. (2007), and they suggested that protein cross-linking is one of the mechanisms for oxidation-induced meat toughening. In their study, the observed larger particle size of oxidized myofibrils was paralleled by oxidation-induced protein cross-linking. Oxidation-induced meat toughening via protein cross-linking is supported by Bao and Ertbjerg (2015), where a hypothesis was proposed for the relationship between oxygen concentrations, shear force and protein oxidation in meat packaged with oxygen. ROS is generated in meat during storage in the presence of oxygen and light, and the generated reactive species react with other meat components leading to oxidized lipids and proteins. Free radicals may transfer between lipids and proteins while one of the consequences of oxidized proteins is to form protein cross-links, and protein cross-linking subsequently lead to tougher meat. Myofibrillar protein cross-linking in high oxygen MAP together with tougher meat were also observed in other studies (Bao et al. 2016; Kim et al. 2010; Moczkowska et al. 2017).

\subsubsection{Role of proteolysis}

Meat tenderization is a complex process and several enzymatic systems have been suggested to play a role (Ouali et al. 2013). The involvement of calpain-1 is thus well documented (Huff-Lonergan, Zhang and Lonergan 2010; Kemp and Parr 2012). In addition, calpain-2 appear to be active in tenderization of pork (Pomponio and Ertbjerg 2012). Also caspases (Kemp and Parr 2012), the proteasome (Houbak, Ertbjerg and Therkildsen 2008) and lysosomal peptidases including cathepsins (Ertbjerg et al. 1999) may contribute. The $20 \mathrm{~S}$ proteasome is able to degrade unfolded protein in an ATP-and ubiquitin-independent fashion and is well known that oxidized proteins are excellent substrates. Heat Shock Protein 70 has in cellular systems been shown to be able to promote degradation of oxidatively damaged proteins by the $20 \mathrm{~S}$ proteasome (Reeg et al. 2016). Hydrolysis of peptide bonds by calpains requires a transfer of electrons between cysteine and histidine residues in the active site (Mehdi 1991). Both cysteine and histidine are susceptible to oxidation (Stadtman and Levine 2003) and therefore oxidation might inhibit 
calpain activity and subsequently reduce the proteolysis of structural proteins and thereby lead to less tender meat. It has thus been shown that purified calpain-1 lose activity upon oxidation (Guttmann et al. 1997; Lametsch, Lonergan, and Huff-Lonergan 2008). In beef, Rowe et al. (2004b) evidenced oxidationinduced inactivation of calpain-1 as the activity and autolysis decreased following irradiation. The milder oxidative stress in high oxygen MAP appear not to affect desmin degradation, suggesting that the proteolysis of myofibrillar proteins is not affected (Bao and Ertbjerg 2015; Kim et al. 2010; Lindahl et al. 2010), although the exact conditions may be of importance as contrasting results have also been reported (Chen et al. 2015; Fu et al. 2017). In the literature, it is generally believed that protein crosslinking, rather than reduced proteolysis, accounts for increased meat toughness during storage in high oxygen MAP.

In addition to inactivation of the enzymes, oxidation by $1-5 \mathrm{mM} \mathrm{H}_{2} \mathrm{O}_{2}$ in the Fenton reaction may also negatively affect the susceptibility of myofibrillar proteins to proteolysis (Santé-Lhoutellier et al. 2007). In contrast, Smuder et al. (2010) claimed that oxidation $\left(25 \mu \mathrm{M} \mathrm{H}_{2} \mathrm{O}_{2}\right)$ enhanced myofibrillar protein degradation by calpain. These conflicting effects of oxidation on proteolysis may due to different degrees of oxidation: moderate oxidation may unfold protein structures while extensive oxidation often leads to more compact protein structures.

\subsection{Protein oxidation in relation to water-holding of meat}

The relationship between oxidative conditions and water-holding properties is summarized in Table 3 with focus on modified atmosphere packaged meat and in Table 4 for meat model systems. Oxidationinduced reactions are very complex and may interact with various water-holding determination methods where salt, pyrophosphate or cooking may be used in the procedures. Currently, there is no general agreement about the effect of protein oxidation on water-holding of fresh meat, especially for meat packaged with oxygen. Lund et al. (2007) found higher drip loss in high oxygen packaged pork as compared to vacuum packaged samples. Oxidation-induced decrease in water-holding is supported by other studies (Delles and Xiong 2014; Zakrys-Waliwander et al. 2012). However, some studies did not find a clear effect of high oxygen MAP on water-holding (Clausen et al. 2009; Lindahl et al. 2010; Łopacka et al. 2017) or an oppsite effect that vacuum packaged meat samples had higher drip loss or purge loss (Chen et al. 2015; Sekar et al. 2006; Yang et al. 2016).

Unlike purge loss or drip loss, moisture absorption of meat in brine containing salt and pyrophosphate was generally better following protein oxidation (Delles and Xiong 2014; Liu et al. 2011). In model oxidation systems, Bertram et al. (2007) studied the water functionality of oxidized myofibrillar proteins using $\mathrm{NMR}$, and reported reduced $\mathrm{T}_{2}$ relaxation times upon oxidation, which was interpret to indicate that oxidation reduced the water-holding of myofibrils. However, a direct proof that oxidation decreased water-holding was not obtained. In other studies, the centrifugation loss of myofibrillar protein gels 
generally increased with oxidation (Decker et al. 1993; Liu et al. 2010; Utrera and Estévez 2012; Xiong et al. 2010). Heating and high salt are often involved in the preparation of myofibrillar protein gel, and they may interact with the oxidation treatment. In contrast using 'raw' myofibrils (no heating and low ionic strength), Bao et al. (2018) showed a decreased centrifugation loss of HClO-oxidized myofibrils.

Most water in muscle is held within the myofibrillar protein matrix (Huff-Lonergan and Lonergan 2005). The volume changes of myofibrils has been suggested as a good model for explaining changes in waterholding observed in meat (Offer and Trinick 1983). Myofibrils are composed of sarcomeres and the volume of a sarcomere is determined by the length and lattice spacing. Recently, a detailed review paper has discussed the structure of the sarcomere in post-mortem muscle and its relation to water-holding (Ertbjerg and Puolanne 2017). In post-rigor raw meat, swelling or shrinking of myofibrils mainly happens laterally as changes in lattice spacing of filaments rather than as changes in sarcomere length. Filament net charges and structural constraints are two important factors that influence the lattice spacing (Smith 2014) and thereby water-holding of meat.

\subsubsection{Role of filament net charges on water-holding}

As explained ealier, myofilaments are net negatively charged in postmortem muscle and the electrostatic forces tend to push the filaments apart. Hamm (1972) concluded that the electrostatic repulsion between myofilaments contributes to water-holding of myofibrils. In addition to electrostatic repulsion, filament net charges could result in an uneven distribution of counter-ions being more concentrated near the filaments and thus creating osmotic forces leading to an increased swelling pressure of myofibrils (Offer and Knight 1988). Both hypotheses (Hamm 1972; Offer and Knight 1988) support that increased filament net charges lead to increased water-holding, and explain the effects of salt content and $\mathrm{pH}$ on water-holding (Puolanne and Halonen 2010). Myofibrillar proteins on average has a pI around 5.0 where filaments carry minimum net charges and therefore a minimum lattice spacing. Filaments gradually become more positively charged at $\mathrm{pH}$ below the $\mathrm{pI}$, while they are negatively charged above $\mathrm{pI}$. The addition of salt affects the water-holding of meat, which may be due to a preferred association of $\mathrm{Cl}^{-}$with myosin filaments as the chaotropic chloride ion probably will be absorbed not only to the outer surface but also to the hollow and hydrophobic part of myosin filaments (Puolanne and Halonen 2010).

Filament charges may also play a role in effects of sarcoplasmic protein denaturation on water-holding. Liu et al. (2016) observed a decreased distance between filaments upon denaturation of sarcoplasmic proteins. As the pI of sarcoplasmic proteins are generally between 6 and 7, they will have net positive charges at ultimate meat $\mathrm{pH}$ of 5.5. The study suggested that denatured sarcoplasmic proteins precipitated onto myofilaments and added positive charges to filaments and thus decreased the net negative charges, which in turn could explain the observed decrease of filament space and water-holding. 
It has been suggested that oxidative modification of the amino acid side chains lead to modified electronic arrangement on myofilaments and the modification of filament charges affect water-holding (Estévez et al. 2011; Utrera and Estévez 2012). Carbonylation of positively charged amino acids (Lys, Arg, His) would lead to a loss of positive charges and thereby increase the net negative charges on myfilaments. As explained above, an increase in the net negative charges is expected to increase water-holding of meat. Bao et al. (2018) found that oxidation with a strong oxidant $(\mathrm{HClO})$ generally increased the water-holding of myofibrils and a hypothesis was proposed (Fig. 5). On one hand, incubation of myofibrils with $\mathrm{HClO}$ led to protein cross-linking and/or aggregation (indicated by increased particle size) which limited swelling of myofibrils. On the other hand, oxidation led to increased net negative charges on myofilaments as indicated by lower isoelectric point of myofibrillar proteins and decreased histidine content. The increased net negative charges increase the repulsion between myofilaments, and therefore the oxidation-induced increase in water-holding may due to a greater effect of increased net charges than opposing effect of protein cross-links.

According to Collins (1997), stable charges of biomolecules are strong chaotropes, such as basic amino acid residues: lysine, arginine and histidine. The structure-breaking chaotropes may make water molecules less structured and induce so-called high density water. The high density water is more mobile and therefore is hypothesized to reduce water-holding (Puolanne and Halonen 2010). Protein carbonylation on lysine, arginine and histidine residues leads to loss of their positive charges, this may decrease the chaotropic effect and therefore increase water-holding.

\subsubsection{Role of structural constraints on water-holding}

The structure of myofibrils bears a large influence on water-holding of meat. Whereas the net charges of myofilaments promote swelling some mechanical forces restrict expansion. Especially the cross-bridges between actin and myosin filaments has been emphasized as important, but also the Z-disc and M-band are structures that form transversal linkages which are believed to add mechanical constraints to swelling (Offer and Trinick 1983). In an oxidizing environment additional cross-links are formed and this will likely strengthen the protein scaffold and thus increase the constraints and tend to reduce the swelling. Liu et al. (2009) proposed a model for the effect of protein oxidation on swelling of myofibrils in the presence of salt. The disulfide cross-links were hypothesized to restrict salt-induced swelling of myofibrils. While protein cross-linking thus may strengthen the meat structure and reduce water-holding, proteolysis on the contrary will weaken the myofibrillar structure and may improve water-holding. Protein oxidation can as described above furthermore inhibit proteolysis in meat and Huff-Lonergan and Lonergan (2005) suggested that oxidation-induced inhibition of proteolysis negatively affects waterholding. Different mechanisms of proteolysis-induced increase in water-holding of meat was proposed by Kristensen and Purslow (2001), Farouk et al. (2012), and Zeng, Li, and Ertbjerg (2017). 


\section{Concluding remarks}

The present review summarized studies about protein oxidation on texture and water-holding of fresh meat. In general, protein oxidation often leads to increased meat toughness, either through formation of protein cross-links or reduced proteolysis of structural proteins. However, the effect of protein oxidation on water-holding is likely a balance between promoting factors (such as increased net filament charges) and opposing factors (such as protein cross-links). The net charges of myofilaments may provide a novel perspective to understand oxidation-induced meat quality changes. The formation of carbonyl groups is a general marker for protein oxidation and specific carbonyls (lysine-derived AAS and arginine- or proline-derived GGS) have been investigated in meat. In meat, histidine has also been suggested to form carbonyls due to oxidation. Histidine is of importance to several aspects in relation to meat quality, as it contributes to meat buffering capacity in the range $\mathrm{pH} 5.5$ to 7 , locates in the reactive center of calpains, and interacts with the heme group in myoglobin. Therefore, histidine and its oxidation products require more attention in the research field of meat science.

\section{Acknowledgements}

The authors would like to thank the China Scholarship Council for financial support.

\section{References}

Al-Bachir, M., and R. Zeinou. 2009. Effect of gamma irradiation on microbial load and quality characteristics of minced camel meat. Meat Sci. 82:119-124.

Aldini, G., I. Dalle-Donne, G. Vistoli, M. R. Facino, and M. Carini. 2005. Covalent modification of actin by 4-hydroxy-trans-2-nonenal (HNE): LC-ESI-MS/MS evidence for Cys374 Michael adduction. J. Mass Spectrom. 40:946-954.

Bailey, A. J. 1972. The basis of meat texture. J. Sci. Food Agr. 23:995-1007.

Baraibar, M. A., J. Hyzewicz, A. Rogowska-Wrzesinska, R. Ladouce, P. Roepstorff, V. Mouly, and B. Friguet. 2011. Oxidative stress-induced proteome alterations target different cellular pathways in human myoblasts. Free Radical Biol. Med. 51:1522-1532.

Bao, Y., S. Boeren, and P. Ertbjerg. 2018. Myofibrillar protein oxidation affects filament charges, aggregation and water-holding. Meat Sci. 135:102-108.

Bao, Y., and P. Ertbjerg. 2015. Relationship between oxygen concentration, shear force and protein oxidation in modified atmosphere packaged pork. Meat Sci. 110:174-179. 
Bao, Y., E. Puolanne, and P. Ertbjerg. 2016. Effect of oxygen concentration in modified atmosphere packaging on color and texture of beef patties cooked to different temperatures. Meat Sci. 121:189-195.

Baron, C. P., and H. J. Andersen. 2002. Myoglobin-induced lipid oxidation: A review. J. Agr. Food Chem. 50:3887-3897.

Berlett, B. S., and E. R. Stadtman. 1997. Protein oxidation in aging, disease, and oxidative stress. $J$. Biol. Chem. 272:20313-20316.

Bertram, H. C., M. Kristensen, H. Østdal, C. P. Baron, J. F. Young, and H. J. Andersen. 2007. Does oxidation affect the water functionality of myofibrillar proteins? J. Agr. Food Chem. 55:23422348.

Bórnez, R., M. Linares, and H.Vergara. 2010. Effect of different gas stunning methods on Manchega suckling lamb meat packed under different modified atmospheres. Meat Sci. 84:727-734.

Buttkus, H. 1967. Reaction of myosin with malonaldehyde. J. Food Sci. 32:432-434.

Cayuela, J. M., M. D. Gil, S. Bañón, and M. D. Garrido. 2004. Effect of vacuum and modified atmosphere packaging on the quality of pork loin. Eur. Food Res. Technol. 219:316-320.

Chen, L., G. Zhou, and W. Zhang. 2015. Effects of high oxygen packaging on tenderness and water holding capacity of pork through protein oxidation. Food Bioprocess Tech. 8:2287-2297.

Clausen, I., M. Jakobsen, P. Ertbjerg, and N. T. Madsen. 2009. Modified atmosphere packaging affects lipid oxidation, myofibrillar fragmentation index and eating quality of beef. Packag. Technol. Sci. 22:85-96.

Collins, K. D. 1997. Charge density-dependent strength of hydration and biological structure. Biophys. J. 72:65-76.

Davies, K. J. 1987. Protein damage and degradation by oxygen radicals. I. general aspects. J. Biol. Chem. 262:9895-9901.

Davies, K. J., M. E. Delsignore, and S. W. Lin. 1987. Protein damage and degradation by oxygen radicals. II. Modification of amino acids. J. Biol. Chem. 262:9902-9907.

Davies, M. J., and R. T. Dean. 1997. Radical-mediated protein oxidation: from chemistry to medicine: Oxford University Press.

Decker, E. A., Y. L. Xiong, J. T. Calvert, A. D. Crum, and S. P. Blanchard. 1993. Chemical, physical, and functional properties of oxidized turkey white muscle myofibrillar proteins. J. Agr. Food Chem. 41:186-189. 
Delles, R. M., and Y. L. Xiong. 2014. The effect of protein oxidation on hydration and water-binding in pork packaged in an oxygen-enriched atmosphere. Meat Sci. 97:181-188.

Delles, R. M., Y. L. Xiong, and A. D. True. 2011. Mild Protein Oxidation Enhanced Hydration and Myofibril Swelling Capacity of Fresh Ground Pork Muscle Packaged in High Oxygen Atmosphere. J. Food Sci. 76:C760-C767.

Ertbjerg, P., M. M. Mielche, L. M. Larsen, and A. J. Møller. 1999. Relationship between proteolytic changes and tenerness in prerigor lactic acid marinated beef. J. Sci. Food Agric. 79:970-978.

Ertbjerg, P., and E. Puolanne. 2017. Muscle structure, sarcomere length and influences on meat quality: A review. Meat Sci. 132:139-152.

Estévez, M. 2011. Protein carbonyls in meat systems: A review. Meat Sci. 89:259-279.

Estévez, M., V. Ollilainen, and M. Heinonen. 2009. Analysis of protein oxidation markers $\alpha-$ aminoadipic and $\gamma$-glutamic semialdehydes in food proteins using liquid chromatography (LC)electrospray ionization (ESI)- multistage tandem mass spectrometry (MS). J. Agr. Food Chem. 57:3901-3910.

Estévez, M., S. Ventanas, M. Heinonen, and E. Puolanne. 2011. Protein carbonylation and waterholding capacity of pork subjected to frozen storage: Effect of muscle type, premincing, and packaging. J. Agr. Food Chem. 59:5435-5443.

Fagan, J. M., B. G. Sleczka, and I. Sohar. 1999. Quantitation of oxidative damage to tissue proteins. Int. J. Biochem. Cell B. 31:751-757.

Farouk, M., N. M. Mustafa, G. Wu, and G. Krsinic. 2012. The "sponge effect" hypothesis: An alternative explanation of the improvement in the waterholding capacity of meat with ageing. Meat Sci. 90:670-677.

Fernandes, R. d. P. P., M. T. de Alvarenga Freire, E. S. M. de Paula, A. L. S. Kanashiro, F. A. P. Catunda, A. F. Rosa, J. C. de C. Baliero, and M. A. Trindade. 2014. Stability of lamb loin stored under refrigeration and packed in different modified atmosphere packaging systems. Meat Sci. 96:554-561.

Flory, P. J. 1953. Principles of polymer chemistry: Cornell University Press.

Frank, D. C., G. Geesink, T. I. Alvarenga, R. Polkinghorne, J. Stark, M. Lee, and R. Warner. 2017. Impact of high oxygen and vacuum retail ready packaging formats on lamb loin and topside eating quality. Meat Sci. 123:126-133. 
Fu, Q., Q. Ge, R. Liu, H. Wang, G. Zhou, and W. Zhang. 2017. Influence of modified atmosphere packaging on protein oxidation, calpain activation and desmin degradation of beef muscles. $J$. Sci. Food Agr. 97:4508-4514.

Fu, Q., R. Liu, W. Zhang, Y. Li, J. Wang, and G. Zhou. 2015. Effects of different packaging systems on beef tenderness through protein modifications. Food Bioprocess Tech. 8:580-588.

Fujimori, E. 1988. Cross-linking of collagen CNBr peptides by ozone or UV light. FEBS Lett. 235:98102.

Giulivi, C., and K. Davies. 1993. Dityrosine and tyrosine oxidation products are endogenous markers for the selective proteolysis of oxidatively modified red blood cell hemoglobin by (the $19 \mathrm{~S}$ ) proteasome. J. Biol. Chem. 268:8752-8759.

Guttmann, R. P., J. S. Elce, P. D. Bell, J. C. Isbell, and G. V. Johnson. 1997. Oxidation inhibits substrate proteolysis by calpain I but not autolysis. J. Biol. Chem. 272:2005-2012.

Hamm, R. 1960. Biochemistry of meat hydration. Adv. Food Res. 10:355-463.

Hamm, R. 1972. Kolloidchemie des Fleisches. Berlin and Hamburg: Paul Parey.

Hawkins, C., D. Pattison, and M. J. Davies. 2003. Hypochlorite-induced oxidation of amino acids, peptides and proteins. Amino Acids. 25:259-274.

Hawkins, C. L., P. E. Morgan, and M. J. Davies. 2009. Quantification of protein modification by oxidants. Free Radical Biol. Med. 46:965-988.

Heath, J., S. Owens, S. Tesch, and K. Hannah. 1990. Effect of high-energy electron irradiation of chicken meat on thiobarbituric acid values, shear values, odor, and cooked yield. Poultry Sci. 69:313-319.

Houbak, M. B., P. Ertbjerg, and M. Therkildsen. 2008. In vitro study to evaluate the degradation of bovine muscle proteins post-mortem by proteasome and $\mu$-calpain. Meat Sci. 79:77-85.

Huff-Lonergan, E., and S. M. Lonergan. 2005. Mechanisms of water-holding capacity of meat: The role of postmortem biochemical and structural changes. Meat Sci. 71:194-204.

Huff-Lonergan, E., W. Zhang, and S. M. Lonergan. 2010. Biochemistry of postmortem muscleLessons on mechanisms of meat tenderization. Meat Sci. 86:184-195.

Hughes, J., S. Oiseth, P. Purslow, and R. Warner. 2014. A structural approach to understanding the interactions between color, water-holding capacity and tenderness. Meat Sci. 98:520-532. 
Irwin, J. A., H. Østdal, and M. J. Davies. 1999. Myoglobin-induced oxidative damage: evidence for radical transfer from oxidized myoglobin to other proteins and antioxidants. Arch. Biochem. Biophys. 362:94-104.

Jayasingh, P., D. P. Cornforth, C. Brennand, C. Carpenter, and D. Whittier. 2002. Sensory evaluation of ground beef stored in high-oxygen modified atmosphere packaging. J. Food Sci. 67:34933496.

Jongberg, S., S. H. Skov, M. A. Tørngren, L. H. Skibsted, and M. N. Lund. 2011. Effect of white grape extract and modified atmosphere packaging on lipid and protein oxidation in chill stored beef patties. Food Chem. 128:276-283.

Jongberg, S., M. A. Tørngren, A. Gunvig, L. H. Skibsted, and M. N. Lund. 2013. Effect of green tea or rosemary extract on protein oxidation in Bologna type sausages prepared from oxidatively stressed pork. Meat Sci. 93:538-546.

Jongberg, S., J. Wen, M. A. Tørngren, and M. N. Lund. 2014. Effect of high-oxygen atmosphere packaging on oxidative stability and sensory quality of two chicken muscles during chill storage. Food Packag. Shelf Life, 1:38-48.

Juntachote, T., E. Berghofer, S. Siebenhandl, and F. Bauer. 2006. The antioxidative properties of Holy basil and Galangal in cooked ground pork. Meat Sci. 72:446-456.

Kanatt, S. R., S. Chawla, and A. Sharma. 2015. Effect of radiation processing on meat tenderisation. Radiat. Phys. Chem. 111:1-8.

Kano, Y., Y. Sakano, and D. Fujimoto. 1987. Cross-linking of collagen by ascorbate-copper ion systems. J. Biochem. 102:839-842.

Karumendu, L., R. Van De Ven, M. Kerr, M. Lanza, and D. Hopkins. 2009. Particle size analysis of lamb meat: Effect of homogenization speed, comparison with myofibrillar fragmentation index and its relationship with shear force. Meat Sci. 82:425-431.

Kato, Y., K. Uchida, and S. Kawakishi. 1992. Oxidative degradation of collagen and its model peptide by ultraviolet irradiation. J. Agr. Food Chem. 40:373-379.

Kemp, C. M., and T. Parr. 2012. Advances in apoptotic mediated proteolysis in meat tenderisation. Meat Sci. 92:252-259.

Kim, Y. H. B., S. Bødker, and K. Rosenvold. 2012. Influence of lamb age and high-oxygen modified atmosphere packaging on protein polymerization of long-term aged lamb loins. Food Chem. 135:122-126. 
Kim, Y. H., E. Huff-Lonergan, J. G. Sebranek, and S. M. Lonergan. 2010. High-oxygen modified atmosphere packaging system induces lipid and myoglobin oxidation and protein polymerization. Meat Sci. 85:759-767.

Kristensen, L., and P. P. Purslow. 2001. The effect of ageing on the water-holding capacity of pork: role of cytoskeletal proteins. Meat Sci. 58:17-23.

Kuriyan, J., B. Konforti, and D. Wemmer. 2012. The molecules of life: Physical and chemical principles. New York: Garland Science, Taylor \& Francis Group.

Lagerstedt, Å., M. L. Ahnström, and K. Lundström. 2011. Vacuum skin pack of beef-A consumer friendly alternative. Meat Sci. 88: 391-396.

Lagerstedt, Å., K. Lundström, and G. Lindahl. 2011. Influence of vacuum or high-oxygen modified atmosphere packaging on quality of beef M. longissimus dorsi steaks after different ageing times. Meat Sci. 87:101-106.

Lametsch, R., J. C. Knudsen, P. Ertbjerg, N. Oksbjerg, and M. Therkildsen. 2007. Novel method for determination of myofibril fragmentation post-mortem. Meat Sci. 75:719-724.

Lametsch, R., S. Lonergan, and E. Huff-Lonergan. 2008. Disulfide bond within $\mu$-calpain active site inhibits activity and autolysis. BBA-Proteins Proteom. 1784:1215-1221.

Lantto, R., E. Puolanne, K. Katina, M. Niemistö, J. Buchert, and K. Autio. 2007. Effect of laccase and transglutaminase on the textural and water-binding properties of cooked chicken breast meat gels. Eur. Food Res. Technol. 225:75-83.

Levine, R. L., D. Garland, C. N. Oliver, A. Amici, I. Climent, A. G.Lenz, . . E. R. Stadtman. 1990. [49] Determination of carbonyl content in oxidatively modified proteins. Methods Enzymol. 186:464-478.

Lindahl, G., Å. Lagerstedt, P. Ertbjerg, S. Sampels, and K. Lundström. 2010. Ageing of large cuts of beef loin in vacuum or high oxygen modified atmosphere-Effect on shear force, calpain activity, desmin degradation and protein oxidation. Meat Sci. 85:160-166.

Liu, G., and Y. L. Xiong. 2000. Electrophoretic pattern, thermal denaturation, and in vitro digestibility of oxidized myosin. J. Agr. Food Chem. 48:624-630.

Liu, G., Y. L. Xiong, and D. Butterfield. 2000. Chemical, Physical, and Gel-forming Properties of Oxidized Myofibrils and Whey-and Soy-protein Isolates. J. Food Sci. 65:811-818.

Liu, J., A. Arner, E. Puolanne, and P. Ertbjerg. 2016. On the water-holding of myofibrils: Effect of sarcoplasmic protein denaturation. Meat Sci. 119:32-40. 
Liu, M., A.-M. Lampi, and P. Ertbjerg. 2018. Unsaturated fat fraction from lard increases the oxidative stability of minced pork. Meat Sci. 143:87-92.

Liu, Z., Y. L. Xiong, and J. Chen. 2009. Identification of restricting factors that inhibit swelling of oxidized myofibrils during brine irrigation. J. Agr. Food Chem. 57:10999-11007.

Liu, Z., Y. L. Xiong, and J. Chen. 2010. Protein oxidation enhances hydration but suppresses waterholding capacity in porcine longissimus muscle. J. Agr. Food Chem. 58:10697-10704.

Liu, Z. L., Y. L. Xiong, and J. Chen. 2011. Morphological Examinations of Oxidatively Stressed Pork Muscle and Myofibrils upon Salt Marination and Cooking To Elucidate the Water-Binding Potential. J. Agr. Food Chem. 59:13026-13034.

Łopacka, J., A. Półtorak, and A. Wierzbicka. 2017. Effect of reduction of oxygen concentration in modified atmosphere packaging on bovine M. longissimus lumborum and M. gluteus medius quality traits. Meat Sci. 124:1-8.

Lund, M. N., M. Christensen, L. Fregil, M. S. Hviid, and L. H. Skibsted. 2008. Effect of high-oxygen atmosphere packaging on mechanical properties of single muscle fibres from bovine and porcine longissimus dorsi. Eur. Food Res. Technol. 227:1323-1328.

Lund, M. N., M. Heinonen, C. P. Baron, and M. Estévez. 2011. Protein oxidation in muscle foods: A review. Mol. Nutr. Food Res. 55:83-95.

Lund, M. N., R. Lametsch, M. S. Hviid, O. N. Jensen, and L. H. Skibsted. 2007. High-oxygen packaging atmosphere influences protein oxidation and tenderness of porcine longissimus dorsi during chill storage. Meat Sci. 77:295-303.

Lund, M. N., C. Luxford, L. H. Skibsted, and M. J. Davies. 2008. Oxidation of myosin by haem proteins generates myosin radicals and protein cross-links. Biochem. J. 410:565-574.

Martinaud, A., Y. Mercier, P. Marinova, C. Tassy, P. Gatellier, and M. Renerre. 1997. Comparison of oxidative processes on myofibrillar proteins from beef during maturation and by different model oxidation systems. J. Agr. Food Chem. 45:2481-2487.

Mehdi, S. 1991. Cell-penetrating inhibitors of calpain. Trends Biochem. Sci. 16: 150-153.

Moczkowska, M., A. Półtorak, M. Montowska, E. Pospiech, and A. Wierzbicka. 2017. The effect of the packaging system and storage time on myofibrillar protein degradation and oxidation process in relation to beef tenderness. Meat Sci. 130:7-15.

Modi, V., P. Sakhare, N. Sachindra, and N. Mahendrakar. 2008. Changes in quality of minced meat from goat due to gamma irradiation. J. Muscle Foods. 19:430-442. 
Morzel, M., P. Gatellier, T. Sayd, M. Renerre, and E. Laville. 2006. Chemical oxidation decreases proteolytic susceptibility of skeletal muscle myofibrillar proteins. Meat Sci. 73:536-543.

Nagy, P., and C. C. Winterbourn. 2010. Redox chemistry of biological thiols. Adv. Mol. Toxicol. 4:183222.

Naylor, G., E. Bartels, T. Bridgman, and G. Elliott. 1985. Donnan potentials in rabbit psoas muscle in rigor. Biophys. J. 48:47-59.

Offer, G., and P. Knight. 1988. Structural basis of water-holding in meat. Part 1: General principles and water uptake in meat processing. In Developments in Meat Science, ed. R. Lawrie, vol. 4, 63171. London: Elsevier Applied Science.

Offer, G., and J. Trinick. 1983. On the mechanism of water holding in meat: the swelling and shrinking of myofibrils. Meat Sci. 8:245-281.

Ouali, A., M. Gagaoua, Y. Boudida, S. Becila, A. Boudjellal, C. H. Herrera-Mendez, and M. A. Sentandreu. 2013. Biomarkers of meat tenderness: Present knowledge and perspectives in regards to our current understanding of mechanisms involved. Meat Sci. 95:854-870.

Park, D., and Y. L. Xiong. 2007. Oxidative modification of amino acids in porcine myofibrillar protein isolates exposed to three oxidizing systems. Food Chem. 103:607-616.

Pattison, D., and M. Davies. 2006. Reactions of myeloperoxidase-derived oxidants with biological substrates: gaining chemical insight into human inflammatory diseases. Curr. Med. Chem. 13:3271-3290.

Pattison, D., C. Hawkins, and M. Davies. 2007. Hypochlorous acid-mediated protein oxidation: how important are chloramine transfer reactions and protein tertiary structure? Biochem. 46:98539864.

Pearce, K. L., K. Rosenvold, H. J. Andersen, and D. L. Hopkins. 2011. Water distribution and mobility in meat during the conversion of muscle to meat and ageing and the impacts on fresh meat quality attributes-A review. Meat Sci. 89:111-124.

Pomponio, L., and P. Ertbjerg. 2012. The effect of temperature on the activity of $\mu$ - and m-calpain and calpastatin during post-mortem storage of porcine longissimus muscle. Meat Sci.:91:50-55.

Puolanne, E., and M. Halonen. 2010. Theoretical aspects of water-holding in meat. Meat Sci. 86:151165.

Purslow, P. P. 2005. Intramuscular connective tissue and its role in meat quality. Meat Sci. 70:435-447. 
Resconi, V. C., A. Escudero, J. A. Beltrán, J. L. Olleta, C. Sañudo, and M. Campo. 2012. Color, lipid oxidation, sensory quality, and aroma compounds of beef steaks displayed under different levels of oxygen in a modified atmosphere package. J. Food Sci. 71:S10-S18.

Reeg, S., T. Jung, J. P. Castro, K. J. A. Davies, A. Henze, and T. Grune. 2016. The molecular chaperone Hsp70 promotes the proteolytic removal of oxidatively damaged proteins by the proteasome. Free Rad. Biol. Med. 99:153-166.

Rowe, L. J., K. Maddock, S. M. Lonergan, and E. Huff-Lonergan. 2004a. Influence of early postmortem protein oxidation on beef quality. J. Anim. Sci. 82:785-793.

Rowe, L. J., K. Maddock, S. M. Lonergan, and E. Huff-Lonergan. 2004b. Oxidative environments decrease tenderization of beef steaks through inactivation of $\mu$-calpain. J. Anim. Sci. 82:32543266.

Rysman, T., S. Jongberg, G. Van Royen, S. Van Weyenberg, S. De Smet, and M. N. Lund. 2014. Protein thiols undergo reversible and irreversible oxidation during chill storage of ground beef as detected by 4, 4'-dithiodipyridine. J. Agr. Food Chem. 62:12008-12014.

Santé-Lhoutellier, V., L. Aubry, and P. Gatellier. 2007. Effect of oxidation on in vitro digestibility of skeletal muscle myofibrillar proteins. J. Agr. Food Chem. 55:5343-5348.

Schaich, K., and W. A. Pryor. 1980. Free radical initiation in proteins and amino acids by ionizing and ultraviolet radiations and lipid oxidation-Part III: Free radical transfer from oxidizing lipids. Crit. Rev. Food Sci. Nutri. 13:189-244.

Sekar, A., K. Dushyanthan, K. Radhakrishnan, and R. N. Babu. 2006. Effect of modified atmosphere packaging on structural and physical changes in buffalo meat. Meat Sci. 72:211-215.

Smith, D. A. 2014. Electrostatic forces or structural scaffolding: what stabilizes the lattice spacing of relaxed skinned muscle fibers? J. Theor. Biol. 355:53-60.

Smuder, A. J., A. N. Kavazis, M. B. Hudson, W. B. Nelson, and S. K. Powers. 2010. Oxidation enhances myofibrillar protein degradation via calpain and caspase-3. Free Radical Biol. Med. 49:1152-1160.

Soglia, F., J. Gao, M. Mazzoni, E. Puolanne, C. Cavani, M. Petracci, and P. Ertbjerg. 2017. Superficial and deep changes of histology, texture and particle size distribution in broiler wooden breast muscle during refrigerated storage. Poultry Sci. 96:3465-3472.

Soglia, F., M. Petracci, and P. Ertbjerg. 2016. Novel DNPH-based method for determination of protein carbonylation in muscle and meat. Food Chem. 197:670-675. 
Soladoye, O., M. Juárez, J. Aalhus, P. Shand, and M. Estévez. 2015. Protein oxidation in processed meat: Mechanisms and potential implications on human health. Compr. Rev. Food Sci. F. 14:106-122.

Sørheim, O., D. Kropf, M. Hunt, M. Karwoski, and K. Warren. 1996. Effects of modified gas atmosphere packaging on pork loin color, display life and drip loss. Meat Sci. 43:203-212.

Stadtman, E., and R. Levine. 2003. Free radical-mediated oxidation of free amino acids and amino acid residues in proteins. Amino Acids, 25:207-218.

Suman, S. P., C. Faustman, S. L. Stamer, and D. C. Liebler. 2006. Redox instability induced by 4hydroxy-2-nonenal in porcine and bovine myoglobins at pH 5.6 and 4 C. J. Agr. Food Chem. 54:3402-3408.

Sun, W., F. Zhou, D. W. Sun, and M. Zhao. 2013. Effect of oxidation on the emulsifying properties of myofibrillar proteins. Food Bioprocess Tech. 6:1703-1712.

Tornberg, E. 1996. Biophysical aspects of meat tenderness. Meat Sci. 43:175-191.

Tørngren, M. 2003. Effect of packing method on color and eating quality of beef loin steaks. Proceedings of 49th International Congress of Meat Science and Technology, Campinas, Brazil, 495-496.

Uchida, K. 2003. Histidine and lysine as targets of oxidative modification. Amino Acids, 25:249-257.

Uchida, K., Y. Kato, and S. Kawakishi. 1992. Metal-catalyzed oxidative degradation of collagen. $J$. Agr. Food Chem. 40:9-12.

Utrera, M., and M. Estévez. 2012. Oxidation of myofibrillar proteins and impaired functionality: underlying mechanisms of the carbonylation pathway. J. Agr. Food Chem. 60:8002-8011.

Utrera, M., D. Morcuende, and M. Estévez. 2014. Fat content has a significant impact on protein oxidation occurred during frozen storage of beef patties. LWT-Food Sci. Technol. 56:62-68.

Vergara, H., and L. Gallego. 2001. Effects of gas composition in modified atmosphere packaging on the meat quality of Spanish Manchega lamb. J. Sci. Food Agr. 81:1353-1357.

Wang, H., Y. Luo, and P. Ertbjerg. 2017. Myofibrillar protein gel properties are influenced by oxygen concentration in modified atmosphere packaged minced beef. Food Chem. 230:475-481.

Warren, C. M., P. R. Krzesinski, and M. L. Greaser. 2003. Vertical agarose gel electrophoresis and electroblotting of high-molecular-weight proteins. Electrophoresis. 24:1695-1702. 
Wagh, R. V., M. K. Chatli, M. Ruusunen, E. Puolanne, and P. Ertbjerg. 2015. Effect of Various Phytoextracts on Physico-chemical, Colour, and Oxidative Stability of Pork Frankfurters. Asian Austral. J. Anim. 28:1178-1186.

Winger, A. M., N. L. Taylor, J. L. Heazlewood, D. A. Day, and A. H. Millar. 2007. Identification of intra-and intermolecular disulphide bonding in the plant mitochondrial proteome by diagonal gel electrophoresis. Proteomics. 7:4158-4170.

Xiong, Y. L., S. P. Blanchard, T. Ooizumi, and Y. Ma. 2010. Hydroxyl Radical and Ferryl-Generating Systems Promote Gel Network Formation of Myofibrillar Protein. J. Food Sci. 75:C215-C221.

Xiong, Y. L., D. Park, and T. Ooizumi. 2009. Variation in the cross-linking pattern of porcine myofibrillar protein exposed to three oxidative environments. J. Agr. Food Chem. 57:153-159.

Yamada, S., T. Funada, N. Shibata, M. Kobayashi, Y. Kawai, E. Tatsuda, . . K. Uchida. 2004. Proteinbound 4-hydroxy-2-hexenal as a marker of oxidized n-3 polyunsaturated fatty acids. J. Lipid Res. 45:626-634.

Yang, X., Y. Zhang, L. Zhu, M. Han, S. Gao, and X. Luo. 2016. Effect of packaging atmospheres on storage quality characteristics of heavily marbled beef longissimus steaks. Meat Sci. 117:50-56.

Yoon, K. 2003. Effect of gamma irradiation on the texture and microstructure of chicken breast meat. Meat Sci. 63:273-277.

Zabielski, J., J. Kijowski, W. Fiszer, and A. Niewiarowicz. 1984. The effect of irradiation on technological properties and protein solubility of broiler chicken meat. J. Sci. Food Agr. 35:662-670.

Zakrys, P., S. Hogan, M. O’Sullivan, P. Allen, and J. Kerry. 2008. Effects of oxygen concentration on the sensory evaluation and quality indicators of beef muscle packed under modified atmosphere. Meat Sci. 79:648-655.

Zakrys, P., M. O’Sullivan, P. Allen, and J. Kerry. 2009. Consumer acceptability and physiochemical characteristics of modified atmosphere packed beef steaks. Meat Sci. 81:720-725.

Zakrys-Waliwander, P., M. O’Sullivan, E. O’Neill, and J. Kerry. 2012. The effects of high oxygen modified atmosphere packaging on protein oxidation of bovine $\mathrm{M}$. longissimus dorsi muscle during chilled storage. Food Chem. 131:527-532.

Zeng, Z., C. Li, and P. Ertbjerg. 2017. Relationship between proteolysis and water-holding of myofibrils. Meat Sci. 131:48-55. 
Zhang, M., F. Li, X. Diao, B. Kong, and X. Xia. 2017. Moisture migration, microstructure damage and protein structure changes in porcine longissimus muscle as influenced by multiple freeze-thaw cycles. Meat Sci. 133:10-18.

Zhang, W., S. Xiao, and D. U. Ahn. 2013. Protein oxidation: basic principles and implications for meat quality. Crit. Rev. Food Sci. Nutr. 53:1191-1201.

Zhou, F., M. Zhao, H. Zhao, W. Sun, and C. Cui. 2014. Effects of oxidative modification on gel properties of isolated porcine myofibrillar protein by peroxyl radicals. Meat Sci. 96:1432-1439. 
Table 1. Summary of literature on the effects of high oxygen MAP on texture of meat.

\begin{tabular}{|c|c|c|}
\hline $\begin{array}{l}\text { Species and } \\
\text { muscle }^{1}\end{array}$ & Key observations & Reference \\
\hline Lamb LD & Shear force $\rightarrow$ & Vergara and Gallego 2001 \\
\hline Beef & $\begin{array}{l}\text { Sensory score for texture likeness of beef patties } \\
\downarrow\end{array}$ & Jayasingh et al. 2002 \\
\hline Beef LD & Tenderness $\downarrow$ & Tørngren 2003 \\
\hline Pork LD & $\begin{array}{l}\text { Carbonyls } \rightarrow \text {, Thiols } \downarrow \text {, Tenderness } \downarrow \text {, Sensory } \\
\text { score for hardness } \uparrow\end{array}$ & Lund et al. 2007 \\
\hline $\begin{array}{l}\text { Pork LD } \\
\text { Beef LD }\end{array}$ & $\begin{array}{l}\text { Myosin cross-linking } \rightarrow \text {, Breaking strength of } \\
\text { single muscle fibre of pork LD } \rightarrow \text {, Breaking } \\
\text { strength of single muscle fibre of beef LD } \uparrow\end{array}$ & Lund et al. 2008 \\
\hline Beef LD & Carbonyls $\rightarrow$, Shear force $\rightarrow$, Tenderness $\rightarrow$ & Zakrys et al. 2008 \\
\hline Beef LD & Protein carbonylation $\uparrow$, Tenderness $\downarrow$ & Clausen et al. 2009 \\
\hline Beef LD & Carbonyls $\rightarrow$, Shear force $\rightarrow$, Tenderness $\rightarrow$ & Zakrys et al. 2009 \\
\hline Lamb LD & Shear force $\uparrow$ & $\begin{array}{l}\text { Bórnez, Linares, and Vergara } \\
2010\end{array}$ \\
\hline $\begin{array}{l}\text { Beef LL, } \\
\text { SM, AD }\end{array}$ & $\begin{array}{l}\text { Protein cross-linking } \uparrow, \text { In LL, Tenderness } \downarrow \\
\text { Compression force } \uparrow \\
\text { SM, AD } \rightarrow\end{array}$ & Kim et al. 2010 \\
\hline Beef LD & Carbonyls $\uparrow$, Shear force $\rightarrow$ & Lindahl et al. 2010 \\
\hline Beef LD & Shear force $\uparrow$, Tenderness $\downarrow$ & $\begin{array}{l}\text { Lagerstedt, Ahnström, and } \\
\text { Lundström } 2011\end{array}$ \\
\hline Beef LD & Carbonyls $\rightarrow$, Shear force $\uparrow$, Tenderness $\downarrow$ & $\begin{array}{l}\text { Lagerstedt, Lundström, and } \\
\text { Lindahl } 2011\end{array}$ \\
\hline Lamb LL & $\begin{array}{l}\text { Protein cross-linking } \uparrow, \text { Shear force of older } \\
\text { animal } \uparrow \\
\text { Shear force of younger animal } \rightarrow\end{array}$ & $\begin{array}{l}\text { Kim, Bødker, and Rosenvold } \\
2012\end{array}$ \\
\hline Beef LD & tenderness $\rightarrow$ & Resconi et al. 2012 \\
\hline Beef LD & Carbonyls $\rightarrow$, Free thiols $\downarrow$, Shear force $\uparrow$ & Zakrys-Waliwander et al. 2012 \\
\hline Lamb LD & Shear force $\rightarrow$ & Fernandes et al. 2014 \\
\hline $\begin{array}{l}\text { Chicken } \\
\text { PM, PL }\end{array}$ & $\begin{array}{l}\text { Free thiols } \downarrow \text {, Protein cross-linking } \uparrow \text {, } \\
\text { Tenderness } \downarrow \text {, Sensory score for firmness in PM } \\
\uparrow, \text { Sensory score for firmness in PL } \rightarrow\end{array}$ & Jongberg et al. 2014 \\
\hline Pork LD & $\begin{array}{l}\text { Free thiols } \downarrow \text {, Protein cross-linking } \uparrow, \text { Shear } \\
\text { force } \uparrow\end{array}$ & Bao and Ertbjerg 2015 \\
\hline Pork LD & Carbonyls $\uparrow$, Shear force $\uparrow$ & Chen et al. 2015 \\
\hline Beef LD & Carbonyls $\rightarrow$, Free thiols $\downarrow$, Shear force $\uparrow$ & Fu et al. 2015 \\
\hline Beef TB & $\begin{array}{l}\text { Free thiols } \downarrow \text {, Protein cross-linking } \uparrow, \text { Hardness } \\
\text { for cooked patties } \uparrow\end{array}$ & $\begin{array}{l}\text { Bao, Puolanne, and Ertbjerg } \\
2016\end{array}$ \\
\hline $\begin{array}{l}\text { Lamb } \\
\text { LD,SM }\end{array}$ & Tenderness $\downarrow$ & Frank et al. 2017 \\
\hline Beef LL & Protein cross-linking $\uparrow$, Shear force $\uparrow$ & Moczkowska et al. 2017 \\
\hline
\end{tabular}


1. $\mathrm{AD}$ adductor; $\mathrm{BF}$ biceps femoris; $\mathrm{LD}$ longissimus dorsi; LL longissimus lumborum; $\mathrm{PM}$ pectoralis major; PL peroneus longus; SM semimembranosus; TB triceps brachii.

' $\uparrow$ ', increase; ' $\rightarrow$ ', no clear effect; ' $\downarrow$ ' decrease (High oxygen MAP compared to packaging with no oxygen or lower oxygen concentrations) 
Table 2. Summary of literature on the effects of oxidative conditions on texture of meat and meat model systems.

\begin{tabular}{|c|c|c|}
\hline $\begin{array}{c}\text { Species and } \\
\text { muscle }^{1}\end{array}$ & Key observations & Reference \\
\hline $\begin{array}{l}\text { aTurkey } \\
\text { breast }\end{array}$ & $\begin{array}{l}\text { Carbonyls } \uparrow \\
\text { Myofibrillar gel strength } \downarrow\end{array}$ & Decker et al. 1993 \\
\hline $\begin{array}{l}\text { aChicken } \\
\text { breast }\end{array}$ & $\begin{array}{l}\text { Carbonyls } \uparrow \text {, Free thiols } \downarrow \text {, Protein cross-linking } \\
\uparrow \\
\text { Storage modulus (G') of myofibrillar gel } \downarrow\end{array}$ & $\begin{array}{l}\text { Liu, Xiong, and Butterfield } \\
2000\end{array}$ \\
\hline aPork SV & $\begin{array}{l}\text { Storage modulus (G') of myofibrillar gel } \uparrow \\
\text { Gel rupture force } \downarrow\end{array}$ & Xiong et al. 2010 \\
\hline aPork LD & $\begin{array}{l}\text { Carbonyls } \uparrow, \text { Free thiols } \downarrow \\
\text { Compression force of myofibrillar gel first } \uparrow \text { and } \\
\text { then } \downarrow \text { with increasing oxidation }\end{array}$ & Zhou et al. 2014 \\
\hline bChicken PS & Shear force $\rightarrow$ & Heath et al. 1990 \\
\hline $\begin{array}{l}{ }^{\text {bChicken }} \\
\text { breast }\end{array}$ & Shear force $\uparrow$ & Yoon 2003 \\
\hline${ }^{b}$ Beef $\mathbf{L L}$ & Carbonyls $\uparrow$, Shear force $\uparrow$ & Rowe et al. 2004a \\
\hline${ }^{b}$ Beef $\mathbf{L L}$ & Shear force $\uparrow$ & Rowe et al. 2004b \\
\hline $\begin{array}{l}{ }^{b} \text { Minced } \\
\text { camel meat }\end{array}$ & Sensory score for texture $\rightarrow$ & Al-Bachir and Zeinou 2009 \\
\hline $\begin{array}{l}{ }^{\text {bChicken }} \\
\text { PM, lamb } \\
\text { BF, buffalo } \\
\text { BF }\end{array}$ & Shear force $\downarrow$ & $\begin{array}{l}\text { Kanatt, Chawla, and Sharma } \\
2015\end{array}$ \\
\hline
\end{tabular}

1. BF biceps femoris; LD longissimus dorsi; LL longissimus lumborum; PM pectoralis major; PS pectoralis superficialis; SV serratus ventralis.

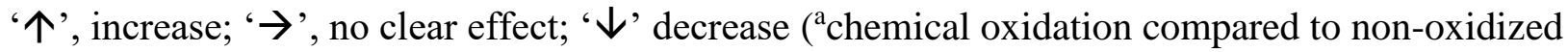
control; birradiation compared to non-irradiated control) 
Table 3. Summary of literature on the effects of high oxygen MAP on water-holding of meat.

\begin{tabular}{|c|c|c|}
\hline $\begin{array}{l}\text { Species and } \\
\text { muscle1 }\end{array}$ & Key observations & Reference \\
\hline Pork LD & Purge loss $\rightarrow$ & Sørheim et al. 1996 \\
\hline Pork LD & Purge loss $\rightarrow$ & Cayuela et al. 2004 \\
\hline Buffalo QF & Purge loss $\downarrow$ & Sekar et al. 2006 \\
\hline Pork LD & Carbonyls $\rightarrow$, Free thiols $\downarrow$, Purge loss $\uparrow$ & Lund et al. 2007 \\
\hline Beef LD & Protein carbonylation $\uparrow$, Purge loss $\rightarrow$ & Clausen et al. 2009 \\
\hline Lamb LD & $\begin{array}{l}\text { Expressible juice (filter paper compression) } \rightarrow \\
\text { Purge loss } \rightarrow \text {, Cook loss } \rightarrow\end{array}$ & Bórnez et al. 2010 \\
\hline Beef LD & Carbonyls $\uparrow$, Purge loss $\rightarrow$, Cook loss $\rightarrow$ & Lindahl et al. 2010 \\
\hline $\begin{array}{l}\text { Pork } \\
\text { (ground) }\end{array}$ & $\begin{array}{l}\text { Carbonyls } \uparrow, \text { Purge loss } \downarrow \text {, Hydration in salt and } \\
\text { pyrophosphate } \uparrow\end{array}$ & Delles, Xiong, and True 2011 \\
\hline Pork LD, PM & $\begin{array}{l}\text { AAS } \uparrow, \text { GGS } \uparrow \\
\text { Water-holding } \downarrow \text { (involves cooking and addition of salt) }\end{array}$ & Estévez et al. 2011 \\
\hline Beef LD & Purge loss $\downarrow$, Cook loss $\uparrow$ & Lagerstedt, Ahnström and Lundström 2011 \\
\hline Beef LD & Carbonyls $\rightarrow$, Thawing loss $\uparrow$, Cook loss $\rightarrow$ & Lagerstedt, Lundström and Lindahl 2011 \\
\hline Beef LD & Carbonyls $\rightarrow$, Free thiols $\downarrow$, Purge loss $\uparrow$ & Zakrys-Waliwander et al. 2012 \\
\hline Pork LL & $\begin{array}{l}\text { Carbonyls } \uparrow, \text { Free thiols } \downarrow, \text { Centrifugation loss } \uparrow \\
\text { Hydration in salt and pyrophosphate } \uparrow \\
\text { Cook loss of oxidized and marinated meat } \rightarrow\end{array}$ & Delles and Xiong 2014 \\
\hline Beef LD & Purge loss $\uparrow$, WHC $\downarrow$ (filter-paper compression) & Bağdatli and Kayaardi 2015 \\
\hline Pork LD & $\begin{array}{l}\text { Carbonyls } \uparrow, \text { Purge loss } \downarrow, \text { Centrifugation loss } \uparrow \\
\mathrm{T}_{2} \text { relaxation time } \rightarrow, \mathrm{P}_{21} \text { (population of immobilized water) } \\
\downarrow \\
\mathrm{P}_{22} \text { (population of free water) } \uparrow\end{array}$ & Chen et al. 2015 \\
\hline Beef $\mathbf{L} \mathbf{L}$ & Carbonyls $\uparrow$, Purge loss $\downarrow$ & Yang et al. 2016 \\
\hline Beef LL,GM & Purge loss $\rightarrow(50 \%, 60 \%$ and $80 \%$ oxygen $)$ & Lopacka et al. 2017 \\
\hline Beef LL, BF & Protein cross-linking $\uparrow$, Cook loss $\rightarrow$ & Moczkowska et al. 2017 \\
\hline Beef TB & Total water loss of myofibrillar gel $\uparrow$ & Wang et al. 2017 \\
\hline
\end{tabular}

BF biceps femoris; GM gluteus medius; LD longissimus dorsi; LL longissimus lumborum; PM psoas major; QF quadriceps femoris; TB triceps brachii. ' $\uparrow$ ', increase; ' $\rightarrow$ ', no clear effect; ' $\downarrow$ ' decrease (High oxygen MAP compared to packaging with no oxygen or lower oxygen concentrations). 
Table 4. Summary of literature on the effects of oxidative conditions on water-holding of meat and meat model systems.

\begin{tabular}{|c|c|c|}
\hline $\begin{array}{c}\text { Species and } \\
\text { muscle }^{1}\end{array}$ & Key observations & Reference \\
\hline $\begin{array}{l}\text { aTurkey } \\
\text { breast }\end{array}$ & Carbonyls $\uparrow$, Centrifugation loss of myofibrillar gels $\uparrow$ & Decker et al. 1993 \\
\hline aPork LD & $\begin{array}{l}\text { Dityrosine } \uparrow, \text { Water content of myofibrillar pellets } \rightarrow \\
\mathrm{NMR} \mathrm{T}_{2} \text { relaxation time } \downarrow \text { (implying reduced water-holding) }\end{array}$ & Bertram et al. 2007 \\
\hline aPork SV & Centrifugation loss of myofibrillar gel $\uparrow$ & Xiong et al. 2010 \\
\hline aPork LL & $\begin{array}{l}\text { Carbonyls } \uparrow, \text { Centrifugation loss } \uparrow, \text { Cook loss } \uparrow \\
\text { Hydration in salt and pyrophosphate } \uparrow\end{array}$ & Liu, Xiong, and Chen 2010 \\
\hline aPork LD & $\begin{array}{l}\text { Carbonyls } \uparrow, \text { Tryptophan fluorescence } \downarrow \text {, Cook loss } \uparrow \\
\text { Hydration in salt and pyrophosphate } \uparrow\end{array}$ & Liu, Xiong, and Chen 2011 \\
\hline aPork LD & $\begin{array}{l}\text { AAS } \uparrow, \text { AAA } \uparrow, S B ~ \\
\text { Centrifugation loss of heat-induced myofibrillar gels } \uparrow\end{array}$ & Utrera and Estévez 2012 \\
\hline aPork LD & $\begin{array}{l}\text { Carbonyls } \uparrow, \text { Free thiols } \downarrow \\
\text { Centrifugation loss of myofibrillar gels } \downarrow \text { and then } \uparrow \text { with oxidation }\end{array}$ & Zhou et al. 2014 \\
\hline aPork LD & Carbonyls $\uparrow$, Free thiols $\downarrow$, Centrifugation loss $\downarrow$ & Bao, Boeren, and Ertbjerg 2018 \\
\hline${ }^{b}$ Chicken & $\begin{array}{l}\text { Expressible juice (filter paper compression) } \uparrow \\
\text { Centrifugation loss } \uparrow \\
\text { Water-holding of heat-induced myofibrillar gel } \downarrow\end{array}$ & Zabielski et al. 1984 \\
\hline${ }^{b}$ Chicken PS & $\begin{array}{l}\text { Cook loss of aged samples } \rightarrow \\
\text { Cook loss of non-aged samples } \downarrow\end{array}$ & Heath et al. 1990 \\
\hline bPork LD & Purge loss $\uparrow$ & Lambert, Smith, and Dodds 1992 \\
\hline $\begin{array}{l}\text { bChicken } \\
\text { breast }\end{array}$ & Cook loss $\rightarrow$ & Yoon 2003 \\
\hline boat legs & Expressible juice (filter paper compression) $\uparrow$ & Modi et al. 2008 \\
\hline $\begin{array}{l}\text { bChicken PM, } \\
\text { lamb BF, } \\
\text { buffalo BF }\end{array}$ & $\begin{array}{l}\text { Cook loss } \uparrow \\
\text { Centrifugation loss of minced meat/salt mixture } \uparrow\end{array}$ & Kanatt et al. 2015 \\
\hline
\end{tabular}

1. BF biceps femoris; LD longissimus dorsi; LL longissimus lumborum; PM pectoralis major; PS pectoralis superficialis; SV serratus ventralis.

2. ' $\uparrow$ ', increase; ' $\rightarrow$ ’, no clear effect; ‘ $\downarrow$ ’ decrease ('chemical oxidation compared to non-oxidized control; ' birradiation compared to nonirradiated control). 
Asp, Glu

sidechains<smiles>[Z]C(=O)[O-]</smiles>

$\mathrm{pKa}$

His sidechain<smiles>[Z6]Cc1c[nH]cn1</smiles><smiles>C=C=C</smiles><smiles>[Z6]Cc1c[nH]cn1</smiles>

$+\mathrm{H}^{+}$

6.6

Cys sidechain

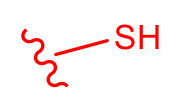

$\rightleftharpoons \quad \xi s^{-}$

$+\mathrm{H}^{+}$

Tyr sidechain<smiles>[Z6]Cc1ccc(O)cc1</smiles><smiles>[Z2]Cc1ccc([O-])cc1</smiles>

Lys sidechain<smiles>[Z6]C[NH]</smiles><smiles>[Z6]CNN</smiles>

$+\mathrm{H}^{+}$

10.5

Arg sidechain<smiles>[Z6]CN=C(N)N</smiles><smiles>C=C=C</smiles><smiles>[Z6]CNC(=N)N</smiles>

Fig. 1. The acid-base equilibria in protein groups. Shown here are sidechains of the backbone that can exist in charged forms, along with their $\mathrm{pK}_{\mathrm{a}}$ values. The acid or base form that is prevalent at $\mathrm{pH} 5.5$ is drawn in red color. The $\mathrm{pK}_{\mathrm{a}}$ values given here are those for isolated amino acids, or unfolded sidechains. Adapted from Kuriyan, Konforti, and Wemmer (2012). 


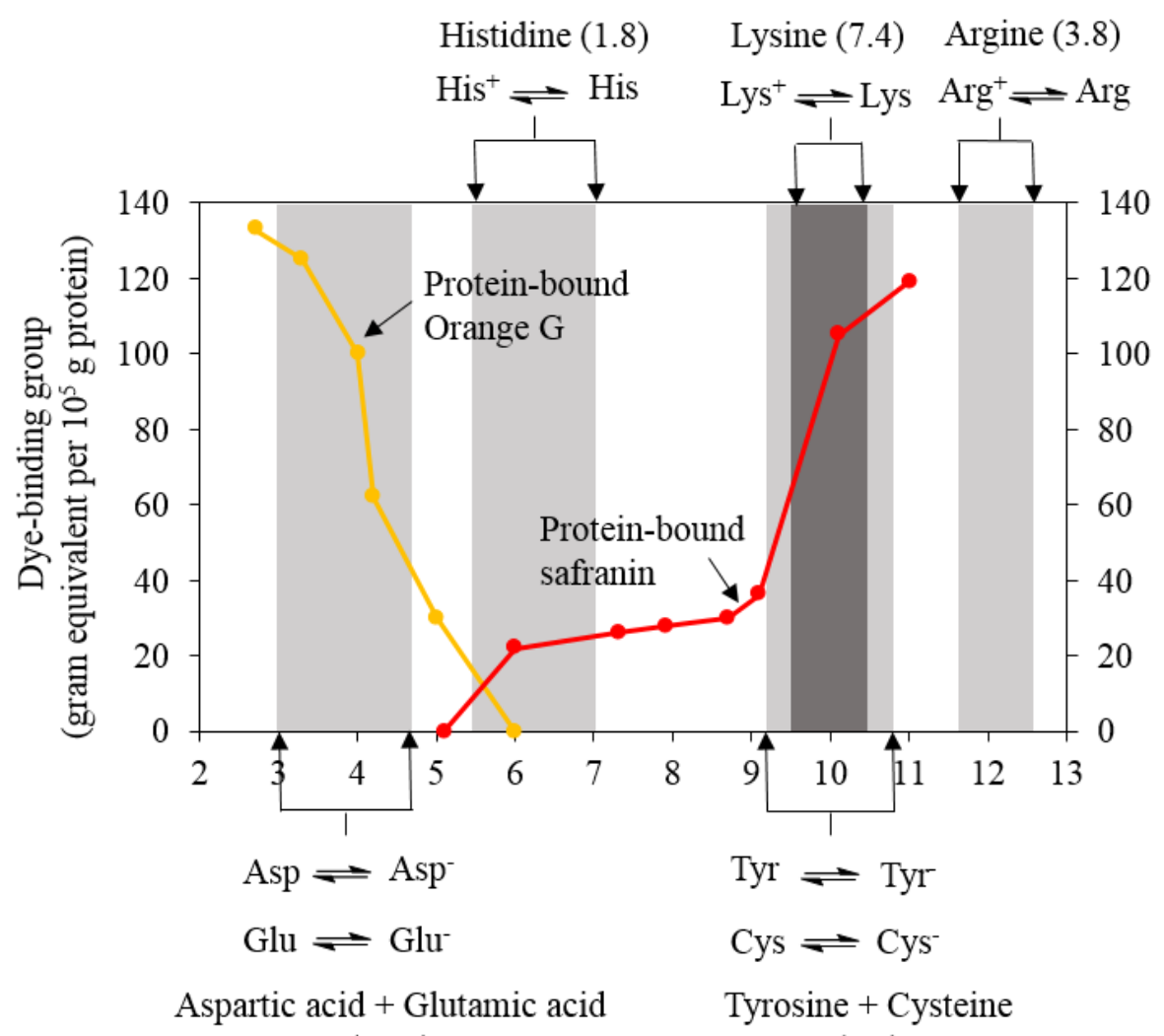

(14.2)

(3.2)

Fig. 2. Effect of $\mathrm{pH}$ on the number of dye-binding groups in myofibrils. Left curve: binding of orange G; right curve: binding of safranin. The equilibria of individual basic or acidic sidechains, together with their relevant $\mathrm{pH}$ ranges and amount in meat are given on the top or at the bottom of the figure. Changes in the amount and sign of net charges are indicated by protein-bound orange $\mathrm{G}$ (binds to positively charged protein) or safranin (binds to negatively charged proteins). The number in the brackets is the amount (moles $/ 10^{4} \mathrm{~g}$ actomyosin) of amino acids. Adapted from Hamm (1972). 
a)<smiles>[3H]CSSCS</smiles>

b)

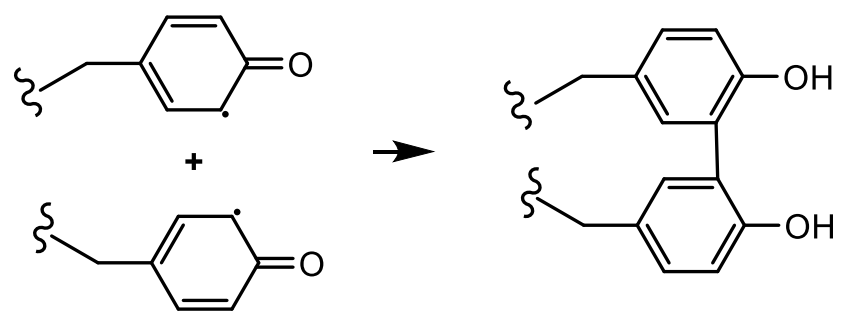

c)<smiles>[Z9]CCCCN=C[Hg]S[Te]</smiles>

d)<smiles>[Z]NC(CC/C=C/C(C=O)CCC(NC)C(C)=O)C(C)=O</smiles>

e)

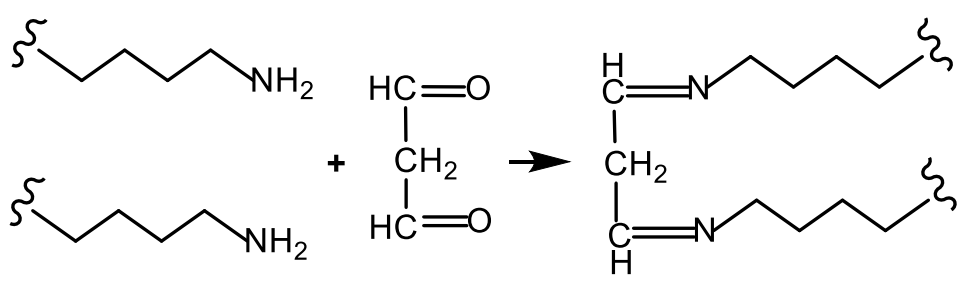

Fig. 3. Illustration of protein cross-linking in meat: a) two cysteine residues form a disulfide bond; b) two tyrosine radicals form a dityrosine cross-link; c) carbonyl-amine cross-link; d) two AAS ( $\alpha$-amino adipic semialdehyde) condensation; e) malondialdehyde (MDA) reacts with two lysine residues. 


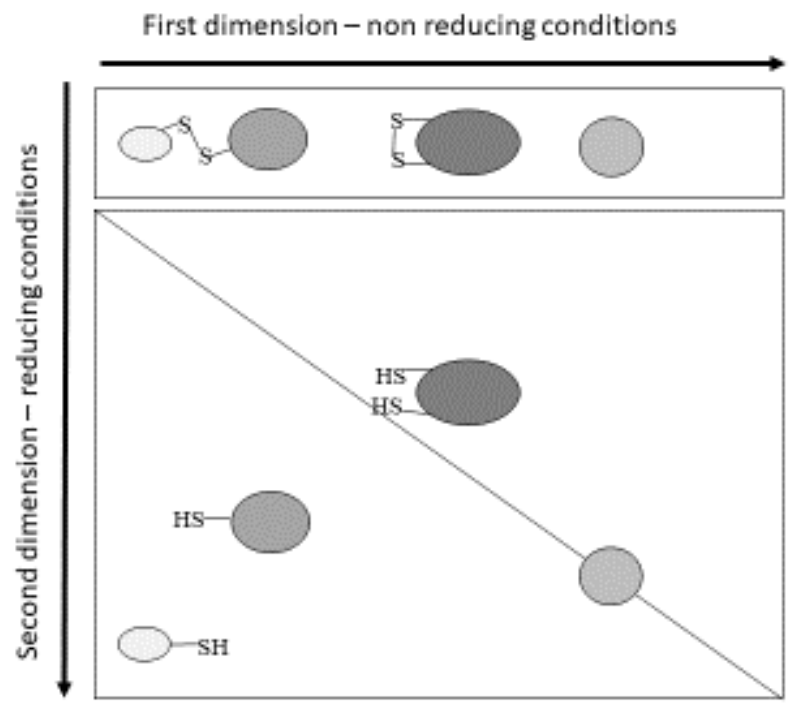

Fig. 4. An illustration of the principle of 2D diagonal SDS-PAGE for the identification of intra- and intermolecular disulfide bonds. Proteins without reducible disulfide bonds run on the diagonal in the second dimension; proteins with intermolecular disulfide bonds migrate below the diagonal; proteins with intramolecular disulfide bonds migrate above the diagonal. 


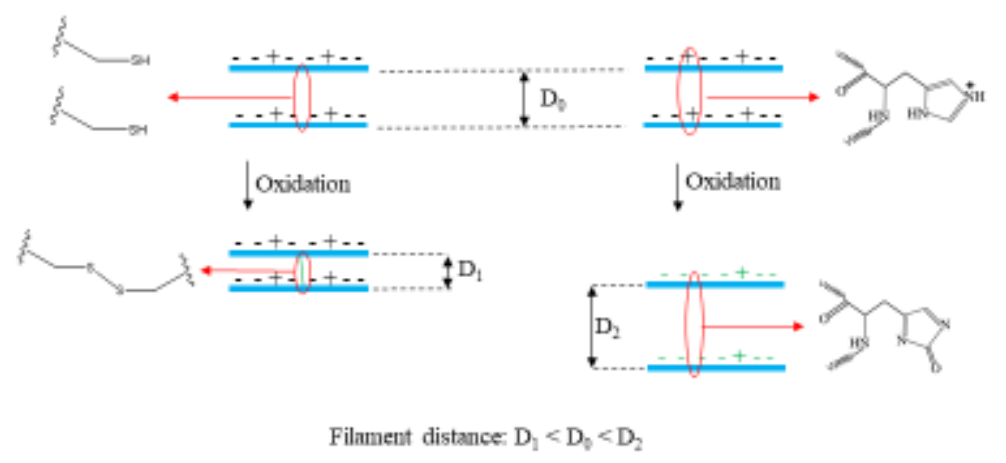

Fig. 5. Model for the effect of myofibrillar protein oxidation on filament spacing. Oxidation leads to two major changes with opposite effects on filament distance: 1) Oxidation leads to formation of disulfide cross-links from two cysteine residues, and thus limits swelling of myofibrils $\left.\left(D_{1}<D_{0}\right) ; 2\right)$ Conversely, histidine residues forms 2-oxo-histidine following oxidation and loses its positive charge and thereby increases in the net negative charges of myofilaments leading to swelling of myofibrils $\left(D_{2}>D_{0}\right)$. 